\title{
An Amcho's Recitation
}

\author{
Pema Bhum, translated by Tenzin Dickie
}

I n 1970 when I got into Malho Trik National Teacher's College, there were about sixty students in my class. To separate us into two sections - an Upper and a Lower Section - the school tested our Tibetan language and mathematics. I found the math test easy because it only tested addition and subtraction, multiplication and division. But I had trouble with the Tibetan test. There was only one part to the Tibetan test and that was a dictation, a dictation of Lin Biao's introduction to the Quotations from Chairman Mao Zedong. Now Quotations from Chairman Mao was a book that we carried on our persons at all times no matter what we were doing. We needed to study the Little Red Book at least once every day and I could even recite many of the passages from the book word for word. But I had never read the introduction to it. During the test as soon as I heard the word 'introduction', I became totally confused. I still remember writing down 'Introduction.' The teacher began: "Comrade Mao Zedong is the greatest Marxist-Leninist of our era," and I tried my best to write down the words as I heard them.

The results were posted the next day. I had made it to the Upper Section. At the time I could hardly believe that I had made the Upper Section when I couldn't even spell the word 'introduction' properly. Now when I think back on this incident, of course it makes sense. All the students who sat that test were around thirteen or fourteen. It was just as we were learning to read some Tibetan that the Cultural Revolution began and put a stop to our education. Many of us who were taking that test could hardly get any words down on paper, let alone spell the words correctly. The ones who could scrawl down some words must have made the Lower Section.

A few days after this test, we began our classes. But we had no textbooks for any of our classes. All the compositions of the great 'Tibetan scholars had been classified as 'poison.' Even the Tibetan language textbooks compiled under Chinese government supervision before 1966 could not be used. So, the text that we used for our Tibetan language class was again "Quotations from Chairman Mao Zedong." After some time, the campaign to study Mao's Three Great Essays was launched; these essays were titled Serve the People; Yugong Moves the Mountain; and In Memory of Norman Bethune. So, we had to study these essays for a while in our Tibetan language class. As soon as this campaign was over, the campaign to study Chairman Mao's Five Essays on Philosophy swept the country. The essays were as follows: 
On Practice; On Contradictions; On the Correct Handling of Contradictions Among the People; Speech at the Chinese Communist Party's National Conference on Propaganda Works; and Where do Correct Ideas Come From? The school began using these essays as our textbook for the class. The school had three different grades at the time, but students in all three grades used the same textbook. The first essay On Practice was the text that we had to study and our teacher was to be Mr. Dorje Tsering. It was Mr. Doring who taught us Tibetan for the first time.

My memories of that first day he came to teach our class are as clear and vivid as if it were yesterday. When he stepped inside the classroom, we collectively sucked in our breath and stopped breathing, so awed and intimidated were we by his fame and his majesty. We all sat up straight in our chairs, stared at his face and waited breathlessly for his first words to us. Mr. Doring came in, put Chairman Mao's Five Essays on Philosophy down on the desk, looked at each of us and said,

"It smells of shit in here. Open the windows."

Not sure what he meant, some of us looked at each other. Some of us kept staring at him, waiting for him to say more.

"Did you all hear me? Open the windows," repeated Mr. Doring. The students who sat near the windows opened the windows.

"If you must smoke, go and smoke in the toilets, inhaling the smell of piss and shit as you do so. Cigarette smoke in the classroom stings my nose and mouth, and I can barely read a book in here."

Then we understood that he meant the smell of "shit" to mean the smell of cigarettes. As it were, students weren't allowed to smoke at school. The other teachers, when they found us smoking, punished us by giving us a long lecture. Of course, the teachers had gotten used to giving this lecture and the students had gotten used to hearing this lecture. Mr. Doring's way of scolding the students who smoked was so novel that it confused us at first. Our class had a few students who smoked, and these students used to smoke in the class between breaks.

Now Mr. Doring called out some names and had these students read out a few lines from On Practice. One or two of them, thinking that a quick reading would impress the teacher, read hastily, tripping over the words and mispronouncing others in their nervousness. If it were another teacher, they would have stopped the student, made the correction and given a scolding all in one go, but not Mr. Doring. He listened to all the students one by one without stopping them, as if they were giving some great reading. 
Then he asked, "Do you guys know what an amcho is?"

Maybe the other students didn't know what an amcho was. They just looked at each other and no one said anything. I knew that an amcho was a monk who went to people's houses to read scripture, but was that the answer Mr. Doring was looking for? I wasn't sure, so I kept quiet.

No one gave an answer. Mr. Doring said, "An amcho is a monk who reads scripture in people's houses."

I felt very sorry that I had not given the answer when I had it.

Mr. Doring continued, "When the amcho read a scripture at people's houses, it is not necessary for the host to hear and comprehend the words. Often it is not even necessary for the amcho himself to hear and comprehend what he is reading. In fact, the faster an amcho reads, the more skilled he is considered to be."

Now we understood what he was saying, which was that we read like amchos.

Next, Mr. Doring wanted to give us a dictation. He told us to mark the words we didn't understand. After he finished dictating, he wanted us to tell him all the words we didn't know.

As he was dictating, he read very slowly. His voice wasn't very loud but he spoke each word very clearly, as if he wanted us to hear that this was the way to read and not the way of the amcho. As he read, his voice sounded dewy and full-throated, as if a lump of saliva had lodged in his throat. I kept wondering why he wouldn't just swallow the saliva and then read.

After Mr. Doring finished reading several passages, just as we wanted, we gave him some words that we didn't know like 'explanation' and 'retinue.'

Then he said, "These are the only words that you don't know?" Nobody answered him and the classroom went very quiet. "There are more words I don't know in this essay than you guys," said Mr. Doring. "Who can explain these terms to me?"

He listed a bunch of revolutionary terms such as society, economy, class, production etc. We came across these terms at least once every day, either in our books or in our lives but there was not a single one of us who could explain what they meant. We sat there dumb and silent. 


\section{Works Cited}

Bhum, Pema. "Dran tho rdo ring ma." Dharamsala: Bod kyi dus bad (Tibet Times), 2006. 